
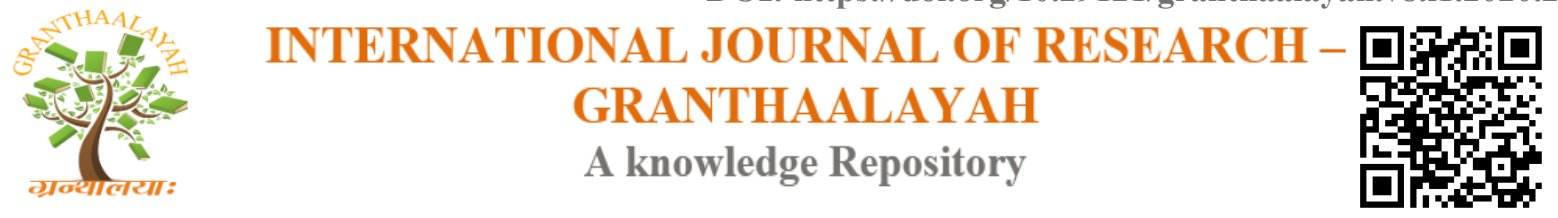

Social

\title{
THE ACTIVE ROLE OF THE FAMILY ON BUILDING THE STUDENTS' CHARACTERS AT UNIVERSITAS KRISTEN INDONESIA
}

\author{
E. Handayani Tyas ${ }^{* 1}$ \\ ${ }^{* 1}$ Mandarin Education Department, Faculty of Education and Teacher Training, Universitas \\ Kristen Indonesia, Jakarta, Indonesia
}

\begin{abstract}
This research is aimed at describing whether parents have an active role in building the character of students and find reasons why it is so. It was done at Universitas Kristen Indonesia, and the respondents were students of Christian Religious Education Department exactly in the second semester. The research method used was the mix method research. The instruments used were the sheet which were analyzed by looking for percentages of all questionnaires (quantitatively) and the interview quidance which were analyzed descriptively (quantitatively). The findings of the research obtained are: a) $18 \%$ of all parents of students who always play a role in building the students character; b) $27 \%$ of all people parents of students who often play a role in building the students character; c) $36 \%$ of all parents of students who sometimes play a role in building the students character, and d) $19 \%$ of all parents of students who does not play a role in building the students character. So, it is concluded that most of the parents play an inactive role in building the students character. As it is expected by the completion of this research is that in building the students' character, the role of parents is needed. For this reason, the role of parents needs to be improved and also the cooperation between parents, campus spiritual institutions, and also lecturers need to be held and improved to build the character of the students.
\end{abstract}

Keywords: Active Role; Parents; Building; Students' Character.

Cite This Article: E. Handayani Tyas. (2020). "THE ACTIVE ROLE OF THE FAMILY ON BUILDING THE STUDENTS' CHARACTERS AT UNIVERSITAS KRISTEN INDONESIA.” International Journal of Research - Granthaalayah, 8(1), 90-104. https://doi.org/10.29121/granthaalayah.v8.i1.2020.256.

\section{Introduction}

In a social environment, the family is the smallest group consisting of only fathers, mothers and children or often also referred to as nuclear family [1]. But in a broader sense, the family can also be a group or social unit that is not only limited to fathers, mothers and children but includes grandparents, uncles, nieces and other relatives or often also referred to as extended family [2]. Of the two definitions given above, the first definition will be the benchmark used in this study. As the smallest social unit, the family has a very decisive role, where the prosperity of a community 
depends on whether or not the welfare of the families in that society. Apart from that, the family has a noble calling that is as a place provider and also loves reciprocity between members of the family, so that each family member can grow and develop into a mature person.

Basically, in a family there are two or more individuals who are joined because of blood relations, marital relations, adoption, in his life in one household, interact with each other and in their respective roles and create and maintain a culture [3] From what has been explained above, it can be seen that in family relationships, something is binding that they must need each other, and complement each other. The main function of the family is as a forum for education, care, and socialization of children in developing the ability of family members to be able to carry out their obligations or responsibilities well and healthy satisfaction. The function of the family is not only limited to children and grandchildren but also the family must be responsible in guiding family members to live according to what God wants. From this, we can see that the family has an active role in guiding all family members in both character-building [4,5].

The environment has an important role in realizing the child's personality. Especially the family environment. Both parents are these role players. The role of the environment in realizing one's personality, both pre-natal and post-natal environments is a problem that cannot be denied, especially the family environment. The family environment is an initial basis of life for every human being. Many servants of God stated that the importance of family influence in children's education on several issues such as personal, cultural, norms, emotional problems and so on [6,7]. The family prepares the means of growth and building of the child's personality from an early age. In other words, the child's personality depends on the thinking and treatment of both parents and their environment. Thus, fulfilled what is the duty of the vocation and family responsibilities as the family desired by God.

The people who play an active role in building the character of someone in the family are father, mother, the biggest child, servant of God, as well as lecturers and the community. It must be stressed that the environment does not affect humanity one hundred per cent, because God created humans accompanied by endeavors and suffrage. The definition of the character referred to according to the Christian faith in this study is the quality possessed by Christians which distinguishes it from non-Christians. Christian character is derived from "spiritual" heredity, which is when we are born in the Spirit so that we have spiritual seeds that are ready to grow in us. This seed is a seed from God, which contains the attributes and characteristics of God that descended on us, His children.

In this study, the author highlights the role of the family in building the students' character compared to the role of other parties such as the campus or church and others, because from the observations made by the researcher stating that currently many families do not carry out their role as family $[8,9]$. As also said before that the family is the most basic and very important aspect in terms of the character building of the child but in carrying out this task many families fail in the place where the research was conducted. From the observation, it was found that by not carrying out the task of family vocation, the growth of students' character has failed as well.

On this basis, the researcher is very interested in writing and conducting research on this topic. So, this research was conducted at Universitas Kristen Indonesia, precisely in the second semester. 
So, based on the background above, then the problem of the study was formulated as follows "How is the active role of the family in building students' character?" With the aim of the research being to describe the active role of the family in building students' character.

\section{Literature Review}

One definition of family is "Mother and father and their children" [10]. This definition is the same as the idea in the western world in English. But the nuclear family (nuclear family) is a modern phenomenon that began as a result of urbanization after the industrial revolution. Another definition in KBBI is closer to the idea in the Bible, for example, "the whole house", "people in the house who are dependents" [11]. So, the definition of family is a small part of a social group consisting of fathers, mothers and children [12]. According to language, the character is a character or habit. Meanwhile, according to psychologists, the character is a system of beliefs and habits that direct the actions of an individual. Therefore, if knowledge about a person's character can be known, then it can also be seen how the individual will behave for certain conditions [13]. From understanding, it turns out that character and character do not have significant differences. Both are defined as actions that occur without further thought because they are embedded in the mind, and in other words, they can be called habits.

The most important element in character formation is thought because the mind, which contains all the programs that are formed from his life experience, is the forerunner of everything [14]. This program then forms a belief system that can eventually form patterns of thinking that can influence behaviour. If the embedded program is following the principles of universal truth, then its behaviour goes in harmony with natural law. As a result, behaviour brings calm and happiness. Conversely, if the program is not following the principles of universal law, then the behaviour brings damage and produces suffering. Therefore, the mind must get serious attention.

Regarding the mind, Joseph Murphy said that in humans there is a mind that has different characteristics. To distinguish these characteristics, the term is called the conscious mind (conscious mind) or objective mind and the subconscious mind (subconscious mind) or subjective mind [15]. Adi W. Gunawan's explanation of the function of the conscious and subconscious mind is interesting to cite. The conscious mind that is physically located in the cortex of the brain is logical and analysis by influencing $12 \%$ of the ability of the brain. While the subconscious mind is physically located in the medulla oblongata which was formed while still in the womb. Therefore, when a baby is born crying, the baby will calm down in his arms because he feels familiar with his mother's heartbeat. The subconscious mind is neutral and suggestive [16]. To understand how the mind works, we need to know that the conscious mind (conscious) is an objective thought that is related to external objects by using the five senses as a medium and the nature of the conscious mind is reasoning. While the subconscious mind (subconscious) is a subjective thought that contains emotions and memories, is irrational, not reason, and cannot be refuted. The work of the subconscious mind becomes very optimal when the work of the conscious mind is increasingly minimal [17].

The conscious and subconscious minds continue to interact. The subconscious mind will carry out what has been suggested to it through a belief system that is born from the conclusions of reasoning from the conscious mind to the external object being observed. Because the subconscious mind 
will continue to follow the impression of the conscious mind, then the conscious mind is likened to a captain while the subconscious mind is likened to a crew who is ready to carry out orders, regardless of whether the command is true or false. Here, the conscious mind can act as a guard to protect the subconscious mind from the influence of external objects. By understanding how the mind works, we understand that mind control becomes very important. With our ability to control thoughts towards goodness, we will easily get what we want, which is happiness. Conversely, if our minds go out of control so that they are focused on evil and evil, then we will continue to suffer suffering, consciously or not. Naturally, from birth until the age of three, or maybe up to about five years, the ability to reason a child has not grown so that the subconscious mind (subconscious mind) is still open and accepts any information and stimulus that is put into it without any selection, starting from parents and family environment [18]. From them, the initial foundation for the character building has been built. The foundation is a certain belief and self-concept. If since childhood both parents always fight and divorce, then a child can draw their conclusions that marriage is suffering. However, if both parents always show mutual respect with a close form of communication, the child will conclude that marriage is beautiful. All of this will have an impact when it grows up.

Furthermore, all life experiences that come from relatives, schools, television, internet, books, magazines, and various other sources add to the knowledge that will deliver a person has greater ability to be able to analyze and reason outside objects. Starting from here, the role of the conscious mind becomes increasingly dominant. Over time, the filtering of information coming through the conscious mind becomes tighter so that not just any information that enters through the five senses can be easily and directly received by the subconscious mind. The more information that is received and the more mature the belief system and mindset that is formed, the clearer the actions, habits, and unique characteristics of each individual. In other words, each individual finally has a unique belief system, self-image, and habit. If the belief system is right and in harmony, good character, and good self-concept, then life will continue to be good and happier. Conversely, if the belief system is not aligned, his character is not good, and his concept is bad, then his life will be filled with many problems and suffering.

If examined further, we can find many explanations about why they get below-average scores. Perhaps, the learning process is not suitable for the type of child, or the instructor is less attractive, or maybe the learning conditions are less supportive. In other words, in essence, children are smart but because of conditions that give them the impression that they are stupid, they believe they are stupid. Therefore, to overcome this problem, several steps need to be considered: a) Selfdiscovery; b) Self-Esteem; c) Self-understanding; d) Confidence; e) Accountability; f) Personal Development; and g) Self Fulfillment $[19,20]$. Besides, education in the family environment also plays an important role in the family. So the family must teach and educate children from childhood, teach independence and direct the vocation of life and direct the child's life motivation $[21,22,23]$.

After teaching ethics and morality, Christian parents must teach their children character. This character speaks of nature, personality, etc. of a human being [24, 25]. Well, the problem is humans often hide their character, as if they were good, especially if in the church $[26,27]$. Our character will appear clearly when we are faced with difficulties. People who have an adult character when faced with difficulties, he is not easy to grumble/grumble or ask others to pay attention to him, but 
people who mature character will try to hold and deny themselves in these difficulties, then try to find a way out and hope in God. Christian parents must teach their children to have mature Christian character, namely by First, learning to deny oneself in adversity. Second, learn to pay attention to other people. Third, learning does not have multiple personalities.

In terms of building the students' character, it is hoped that the active role of the family, especially fathers and mothers, in guiding their children to be children who fear God or become children following God's will. By maximizing the active role of the family in building the character of student children, it will grow well. By carrying out the active role of the family in the character building, then comes the character and personality of family children following the Bible. The principles that can be done are. Some important principles that families must do to help children develop good self-excavation: a) Self-discovery if the family can help children to "find" themselves (see their attributes, see what God has planted in them) then he will admire what God is doing in him; b) Self-respect as a family, we must foster children to respect or respect themselves because God himself has created and shaped him by giving special potential to be developed. Selfrespect will be the strength to protect yourself from the destruction that can strike at any time; c) Self-understanding has a self-recognition is very important, where a child can find out who he is, where the advantages and disadvantages. This self-understanding is the beginning of wisdom. Knowing oneself will bring a person to understand his limitations and understand the infinities of God.

Here is the wise key: with faith a finite person is holding to the infinite; d) Confidence (selfconfidence), as a family must uphold children so that in their lives in the world they have confidence, namely the belief that they can do something. But, on the other hand, we should not sue the child beyond what he can do, this will only undermine the child's self-confidence. When the abilities and self-confidence of children are balanced, a child will be a healthy soul; e) Selfresponsibility (self-responsibility), a child can grow into adulthood if he learns the meaning of responsibility. How in his life he learned to think about others, be selfless, and be generous; f) Self-development - the drive to always develop ourselves is a healthy impulse if what we develop is our abilities and potentials that are following God's leadership, not according to our fleshly desires; and g) Fulfillment of self, educate children to make life plans based on the principles of life following the Bible so that they have their fences and can walk according to their path. Those principles will become a discipline for themselves one day when they are free from our care.

\section{Methodology}

This research was conducted at the Indonesian Christian University precisely in the Christian Religious Education Study Program and this research will be conducted in September. The subjects in this study were the second-semester students in 20 Christian Religious Education Study Programs. In this research, the writer uses descriptive qualitative research to describe the situation and events that occur in the field $[28,29,30]$. The data collection technique uses observation and interview techniques and questionnaires [31,32,33]. After the data is collected completely the next stage is the data analysis stage by looking for the percentage of all the questionnaire responses that have been collected, then determining the score of all data, to determine the scoring of all questions and statements of each item with the weight value for each responses as follows [34]: 
Table 1: Score Alternative Items for Respondents' Responses

\begin{tabular}{|l|c|c|c|}
\hline Positive & \multicolumn{2}{c|}{ Negative } \\
\hline Responses & Score & Responses & Score \\
\hline always & 4 & always & 1 \\
\hline often & 3 & often & 2 \\
\hline sometimes & 2 & sometimes & 3 \\
\hline never & 1 & never & 4 \\
\hline
\end{tabular}

Then by looking at the average score of student responses with the following classification [35]:

Table 2: Questionnaire Score Classification

\begin{tabular}{|c|c|}
\hline Classification & Explanation \\
\hline $25-50$ & Low \\
\hline $51-75$ & Everage \\
\hline $76-100$ & high \\
\hline
\end{tabular}

and after all, data are presented, conclusions will be drawn regarding the active role of parents in building the character of students of Christian Religious Education Study Program students.

\section{Result and Discussion}

This research was a mix method research, it was conducted at Universitas Kristen Indonesia, Jakarta. The respondents of the research were the students of Christian Religious Department, exactly the second-semester students. The instrument of the research was: a) questionnaire sheet the researcher distributes the questionnaire sheets about the active role of the family in character building to the student; and b) interview guidance - the researcher interviewed students about their family relationships. After the data is obtained through a questionnaire given to students, then the data is processed in tabular form using a descriptive percentage technique. The results of the questionnaire processing in the percentage descriptive technique using the formula:

$\mathrm{P}=$ percentation

$$
P=\frac{F}{N} \times 100
$$

$\mathrm{F}=$ Frequency

$\mathrm{N}=$ Number of Cases

The results of the questionnaire are included in the tabulation which is the process of changing data and data collection instruments (questionnaires) into tables of numbers (percentages), can be seen more clearly in the section below:

Table 3: Questionnaire Data Tabulation

\begin{tabular}{|l|l|c|c|c|c|}
\hline No & Statement & \multicolumn{3}{|c|}{ Frequency of Responses } \\
\hline & & Always & Often & Sometimes & Never \\
\hline 1 & Statement 1 & $8(40 \%)$ & $8(40 \%)$ & $3(18 \%)$ & $1(2 \%)$ \\
\hline 2 & Statement 2 & $1(9 \%)$ & $2(11 \%)$ & $14(65 \%)$ & $3(15 \%)$ \\
\hline
\end{tabular}




\begin{tabular}{|l|l|c|c|c|c|}
\hline 3 & Statement 3 & $8(38 \%)$ & $2(12 \%)$ & $6(31 \%)$ & $4(19 \%)$ \\
\hline 4 & Statement 4 & $3(12 \%)$ & $9(47 \%)$ & $7(36 \%)$ & $1(5 \%)$ \\
\hline 5 & Statement 5 & $3(17 \%)$ & $4(19 \%)$ & $11(55 \%)$ & $2(9 \%)$ \\
\hline 6 & Statement 6 & $2(11 \%)$ & $7(34 \%)$ & $5(28 \%)$ & $6(27 \%)$ \\
\hline 7 & Statement 7 & $4(22 \%)$ & $5(24 \%)$ & $8(21 \%)$ & $3(13 \%)$ \\
\hline 8 & Statement 8 & $3(16 \%)$ & $8(40 \%)$ & $7(34 \%)$ & $2(10 \%)$ \\
\hline 9 & Statement 9 & $5(14 \%)$ & $5(27 \%)$ & $7(33 \%)$ & $3(26 \%)$ \\
\hline 10 & Statement 10 & $4(21 \%)$ & $8(34 \%)$ & $5(26 \%)$ & $3(19 \%)$ \\
\hline 11 & Statement 11 & $2(12 \%)$ & $5(26 \%)$ & $7(35 \%)$ & $4(27 \%)$ \\
\hline 12 & Statement 12 & $7(38 \%)$ & $10(49 \%)$ & $2(9 \%)$ & $1(4 \%)$ \\
\hline 13 & Statement 13 & $1(4 \%)$ & $3(21 \%)$ & $13(66 \%)$ & $2(9 \%)$ \\
\hline 14 & Statement 14 & $5(21 \%)$ & $2(16 \%)$ & $9(45 \%)$ & $4(18 \%)$ \\
\hline 15 & Statement 15 & $4(21 \%)$ & $3(16 \%)$ & $5(23 \%)$ & $8(39 \%)$ \\
\hline 16 & Statement 16 & $2(11 \%)$ & $3(14 \%)$ & $7(34 \%)$ & $8(41 \%)$ \\
\hline 17 & Statement 17 & $7(32 \%)$ & $6(30 \%)$ & $5(26 \%)$ & $2(12 \%)$ \\
\hline 18 & Statement 18 & $4(22 \%)$ & $9(44 \%)$ & $5(27 \%)$ & $2(17 \%)$ \\
\hline 19 & Statement 19 & $2(13 \%)$ & $8(38 \%)$ & $3(14 \%)$ & $7(35 \%)$ \\
\hline 20 & Statement 20 & $6(31 \%)$ & $5(24 \%)$ & $6(31 \%)$ & $2(14 \%)$ \\
\hline 21 & Statement 21 & $2(11 \%)$ & $5(25 \%)$ & $7(33 \%)$ & $6(31 \%)$ \\
\hline 22 & Statement 22 & $8(36 \%)$ & $4(26 \%)$ & $5(32 \%)$ & $3(5 \%)$ \\
\hline 23 & Statement 23 & $4(19 \%)$ & $5(27 \%)$ & $8(42 \%)$ & $3(12 \%)$ \\
\hline 24 & Statement 24 & $4(22 \%)$ & $5(25 \%)$ & $6(28 \%)$ & $5(25 \%)$ \\
\hline 25 & Statement 25 & $3(16 \%)$ & $7(35 \%)$ & $4(18 \%)$ & $6(31 \%)$ \\
\hline 26 & Statement 26 & $4(22 \%)$ & $6(33 \%)$ & $8(36 \%)$ & $2(9 \%)$ \\
\hline 27 & Statement 27 & $3(17 \%)$ & $6(41 \%)$ & $3(17 \%)$ & $8(33 \%)$ \\
\hline 28 & Statement 28 & $3(14 \%)$ & $4(21 \%)$ & $2(53 \%)$ & $11(12 \%)$ \\
\hline 29 & Statement 29 & $0(0 \%)$ & $0(0 \%)$ & $9(45 \%)$ & $11(55 \%)$ \\
\hline 30 & Statement 30 & $5(26 \%)$ & $7(36 \%)$ & $7(36 \%)$ & $1(2 \%)$ \\
\hline TOTAL & 114 & 162 & 205 & 115 \\
\hline$\%$ & & $18 \%$ & $27 \%$ & $36 \%$ & $19 \%$ \\
\hline
\end{tabular}

The data in this first statement shows that out of 20 students, $40 \%$ of families always let their children go to church of their own volition every Sunday, and $40 \%$ of families often let their children go to church of their own volition and $18 \%$ sometimes and $2 \%$ who never allowed his child to go to church of his own volition. What this means is that among all more Sunday schools there are almost more than half who like to go to church every week and there are a small portion of Sunday schools that go to church on a family wish.

The data in the second statement shows that of 20 students, only $9 \%$ of families always motivate their children to go to church, $11 \%$ of families often motivate their children to go to church, and $65 \%$ of families sometimes motivate their children to go to church, and the last $15 \%$ never motivated their children to go to church. What this means is that among all more Sunday schools there are almost more than half who like to go to church without the motivation of parents. And there is a small portion of Sunday schools that go to church with family motivation. 
The data in the third statement shows that out of 20 students, only $38 \%$ of families always require their children to go to church, and $12 \%$ of families often require their children to go to church, and $31 \%$ of families sometimes require their children to go to church, and finally $19 \%$ of families who never required their children to go to church. What this means is that among all Sunday school families there are almost fewer families that require their children to go to church and some of the Sunday school families that require their children to go to church.

The data in the fourth statement shows that out of 20 students, only $12 \%$ of families do not always require their children to go to church, $47 \%$ of families do not often require their children to go to church, and $36 \%$ of families sometimes do not require their children to go to church. Finally, there are $19 \%$ of families who never require their children to go to church. What this means is that among all more Sunday school parents there are almost more families who do not require their children to go to church and some of the Sunday school families that require their children to go to church.

The data in the fifth statement shows that out of 20 students, only $17 \%$ of families always do not want to know their children go to church or do not go, and $19 \%$ of families often do not want to know their children go to church or do not go, and 55\% of families sometimes want to know their children go to church or not go, and finally, $9 \%$ of families want to know their children go to church or don't go. What this means is that among all Sunday school parents there are more than almost half of the families not wanting to know their children are going to church or not going, and some of the Sunday school families care about their children going to church.

The data in the sixth statement shows that out of 20 students, only $11 \%$ of families always provide for their children's needs at Sunday school, and 34\% of families often always provide for their children's needs at Sunday School, and $28 \%$ of families sometimes always provide for their children's needs at Sunday School, and finally, $27 \%$ of families do not always provide for their children's needs at Sunday school. What this means is that among all Sunday school families there are almost more than half of families that require their children to go to church and some of the student families who require their children to go to church.

The data in the seventh statement shows that out of 20 students, only $22 \%$ of families always neglect programs related to spirituality both in church and on television, and $24 \%$ of families often ignore programs related to spirituality both in church and in television, and $41 \%$ of families sometimes do not neglect programs that have something to do with spirituality both in church and on television, and finally, $13 \%$ of families have never neglected programs related to spirituality both in church and in television. What this means is that among all student families there are almost more than half of families who ignore programs related to spirituality both in church and on television, and some of the student families who do not ignore events related to spirituality both in church and on television.

The data in the eighth statement shows that out of 20 students, only $16 \%$ of families always ask what their children have learned and gotten back from church, and $40 \%$ of families often ask what their children have learned and got back from church, and $34 \%$ of families sometimes do not ask back what their children have learned and got back from church, and finally, $10 \%$ of families never ask back what their children have learned and got back from church. What this means is that among 
all student families there are almost more than half of families who ask back what their children have learned and got back from church.

The data in the ninth statement shows that out of 20 students, only $14 \%$ of families always never ask what their children have learned in college, and $27 \%$ of families often never ask what their children have learned in college, and 33\% of families sometimes do not have asked what their children have learned at a student, and most recently there are $26 \%$ of families who have not asked what their children have learned at a student. The meaning is that among all student families there are almost more than half of families who ask what their children have learned at the student and some of the student families who have never asked what their children have learned at the student.

The data in the tenth statement shows that of 20 students, only $21 \%$ of families always guide their children to stay close to God, and $34 \%$ of families often guide their children to stay close to God, and $26 \%$ of families sometimes guide their children to stay alive close to God, and finally, $19 \%$ of families guide their children to stay close to God. The meaning is that among all student families there are almost more than half of families that guide their children to stay close to God, and some of the student families who do not guide their children to stay close to God.

The data in the eleventh statement shows that out of 20 students, only $12 \%$ of families always teach their children to pray, and $26 \%$ of families often teach their children to pray, and $35 \%$ of families sometimes teach their children to pray, and finally $27 \%$ of families not teach their children to pray. What this means is that among all student families there are more than half of families who teach their children to pray, and some of the family families who do not teach their children to pray.

The data in the twelfth statement shows that of 20 students, only $38 \%$ of families always pay attention to their children's daily behaviour, and $49 \%$ of families often pay attention to their children's daily behaviour, and $9 \%$ of families sometimes pay attention to their children's daily behaviour day, and finally, $4 \%$ of families do not pay attention to their children's daily behaviour. The meaning is that among all student families there are almost more than half of families who pay attention to their children's daily behaviour, and some of the student families who pay attention to their children's daily behaviour.

The data in the thirteenth statement shows that out of 20 students, only $4 \%$ of families always do not care about their children's daily behaviour, and $21 \%$ never care about their children's daily behaviour, and $66 \%$ of families sometimes never care about their children's behaviour every day, and finally, there are $9 \%$ of families who never care about their children's daily behaviour. The meaning is that among all student families there are almost more than half of families who still care about their children's daily behaviour and some of the student families who never care about their children's daily behaviour.

The data in the fourteenth statement shows that out of 20 students, only $21 \%$ of families always reprove their children with love, and $16 \%$ of families often reprimand their children with love, and $45 \%$ of families sometimes reprimand their children with love, and finally, $18 \%$ of families who does not rebuke his child with love. The meaning is that among all student families there are almost 
more than half of families that require their children to go to church and some of the student families who require their children to go to church.

The data in the fifteenth statement shows that out of 20 students, only $21 \%$ of families always reprimand their children with violence, and $16 \%$ of families often abuse their children with violence, and $23 \%$ of families sometimes abuse their children with violence, and finally $39 \%$ of families who never rebuked their children with violence. What this means is that among all more student families there are almost more than half of families who abuse their children with violence, and some of the family families who abuse their children with violence.

The data in the sixteenth statement shows that out of 20 students, only $11 \%$ of families are often angry with their children, and $14 \%$ of families are often angry with their children, and $34 \%$ of families are sometimes angry with their children, and the last is $41 \%$ of families who never get angry at their children. The meaning is that among all student families more families are not angry at their children.

The data in the seventeenth statement shows that out of 20 students, only $32 \%$ of families always give praise when their children do something good, and $30 \%$ of families often give praise when their children do something good, and $26 \%$ of families sometimes always give praise when their children do something good, and finally $12 \%$ of families always give praise when their children do something good. The meaning is that among all student families, more than half of families always give praise when their children do something good, and some families do not always give praise when their children do something good.

The data in the eighteenth statement shows that out of 20 students, only $22 \%$ of families are always cohesive with their children, and $44 \%$ of families are often always cohesive with their children, and $27 \%$ of families are sometimes always cohesive with their children, and finally $17 \%$ of families who have not always been united with their children. What this means is that among all more student families there are almost more than half of families that are always cohesive with their children, and there are some student families that are not always cohesive with their children.

The data in the nineteenth statement shows that of 20 students, only $13 \%$ of families always do not provide time for their children to play together with their friends, and $14 \%$ of families often do not make time for their children to play together with their friends, and 38 families sometimes they don't provide time for their children to play together with their friends, and finally, $35 \%$ of families never make time for their children to play together with their friends. The meaning is that among all student families there are more than half of families who do not provide time for their children to play together with their friends, and there are some of the student families do not make time for their children to play together with their friends.

The data in the twentieth statement shows that out of 20 students, only $31 \%$ of families always pay attention to their children in acting and speaking, and $24 \%$ pay attention to their children in acting and speaking, and $31 \%$ of families sometimes pay attention to their children in acting and speaking. and finally, there are $14 \%$ of families who never pay attention to their children in acting and speaking. The meaning is that among all student families there are more than half of families who 
pay attention to their children in acting and speaking, and there are some of the student families who do not pay attention to their children in acting and speaking.

The data in the twenty-first statement shows that out of 20 students, only $11 \%$ of families always provide time to hear their children's stories about how they feel, and $25 \%$ of families often make time to hear their children's stories about how they feel, and 33\% of families sometimes it takes time to hear their children's stories about how they feel, and finally, $31 \%$ of families never take the time to hear their children's stories about how they feel. What this means is that among all student families there are more than half of families that less require their children to go to church and make time to hear their children's stories about how they feel, and some of the student families who require their children to go to church and make time to hear their children's stories about how they feel.

The data in the twenty-second statement shows that out of 20 students, only $36 \%$ of families always take the time to follow their children on special days, and $26 \%$ of families often take the time to follow their children on special days, and 32\% of families sometimes taking the time to follow their children on special days, and finally $5 \%$ of families who never take the time to follow their children on special days. What this means is that among all student families there are more than half of families who take the time to follow their children on special days, and there are some family families who do not take the time to follow their children on special days.

The data in the twenty-third statement shows that out of 20 students, only $19 \%$ of families always respond positively to their children's actions that are not following Christian behaviour, and 27\% of families often respond positively to their children's actions that are not following Christian behaviour, and $42 \%$ of families sometimes respond positively to the actions of their children that are not following Christian behaviour, and finally, there are $12 \%$ of families who have never responded with positive actions that their children do not comply with Christian behaviour. What this means is that among all student families there are half of the families who respond positively to their children's actions that are not following Christian behaviour and some of the student families who respond positively to their children's actions that are not following Christian behaviour.

The data in the twenty-fourth statement above shows that sometimes students behave ignorantly towards the learning difficulties they experience. This is because students might learn because of the coercion of their parents. The data in the twenty-fifth statement shows that out of 20 students, only $16 \%$ of families always tell spiritual stories that can amaze their children, and $35 \%$ of families often tell spiritual stories that can amaze their children, and $18 \%$ of families sometimes tell spiritual stories that can amaze their children, and finally, $31 \%$ of families never tell spiritual stories that can amaze their children. This means that among all student families some families tell spiritual stories that can amaze their children, and some of the student families never tell spiritual stories that can amaze their children.

The data in the twenty-sixth statement shows that out of 20 students, only $22 \%$ of families always emphasize to their children that God is good, and 33\% of families often stress to their children that God is good, and 36\% of families sometimes stress to their children that God that's good, and finally $9 \%$ of families never emphasize to their children that God is good. The meaning is that 
among all student families there are almost more than half of families that emphasize to their children that God is good, and some of the student families who do not emphasize to their children that God is good.

The data in the twenty-seventh statement shows that out of 20 students, only $17 \%$ of families always teach their children to love one another through behaviour and deeds, and $41 \%$ of families often teach their children to love one another through behaviour and deeds, and $17 \%$ of families sometimes teach life to one another to love their children through behaviour and deeds, and finally, there are $33 \%$ of families who have never taught life to love one another with children through behaviour and deeds. The meaning is that among all student families there are almost more than half of families that teach their children to love one another through behaviour and deeds, and some of the student families do not teach their children to love one another through behaviour and deeds.

The data in the twenty-eighth statement shows that out of 20 students, only $14 \%$ of families always feel tired of advising their children, and $21 \%$ of families often feel tired of advising their children, and $12 \%$ of families sometimes feel tired of advising their children, and finally, $53 \%$ families who have never felt bored advising their children. The meaning is that among all student families there are more than half of families who do not feel fed up advising their children, and some of the student families who feel fed up advising their children.

The data in the twenty-ninth statement shows that out of 20 students, only no family always looks for their children's mistakes, and no family often looks for their children's mistakes, and $45 \%$ of families sometimes require their children to go to church, and the latter is $55 \%$ of families who never find fault with their children. The meaning is that among all student families, almost all families who never often find fault with their children.

The data in the thirtieth statement shows that out of 20 students, only $26 \%$ of families often testify of God's goodness to their children, and $36 \%$ of families often testify of God's goodness to their children, and $36 \%$ of families sometimes testify of God's goodness to their children, and finally, there are $2 \%$ of families who don't often testify of God's goodness to their children. The meaning is that among all family students almost all want to witness the goodness of God to their children.

From the entire table above it is known that the total score of parental responses can be classified as follows:

Table 4: Total Percentage of Student Questionnaire Responses

\begin{tabular}{|l|c|}
\hline Response's Alternative & percentation \\
\hline always & $18 \%$ \\
often & $27 \%$ \\
sometimes & $36 \%$ \\
never & $19 \%$ \\
\hline TOTAL & $100 \%$ \\
\hline
\end{tabular}

Thus it can be concluded that from 20 questionnaires collected, and after the data were analyzed the results are as follows: there are $18 \%$ of all parents of students who always play a role in 
character building of students, $27 \%$ of all people parents of students who often play a role in the character building and growth of students 'faith, 36\% of all parents of students who sometimes play a role in the character building and growth of students' faith, and the last is $19 \%$ of people all parents of students who do not play a role in building the character and growth of students' faith.

From the description and analysis of the data that has been presented above, it can be concluded that parents are not too involved in the character building of students in 2011. From the results of observations made by researchers on the subjects of this study are as follows: It was found that character building is very large, not determined by parents. Where parents are not too involved in building the students' character at Universitas Kristen Indonesia. This can be seen in the list of attachments in the Observation section. And from the interview data conducted by researchers of students in this study have been obtained data that is needed in this study. Where the data obtained says that indeed the condition of students' parents did not support their children to participate in student activities held at church or on campus. For example, if there is work that has not been done on a typical day, some parents will tend to invite their children to participate in completing it or they are told to stay home guard, and the same results were also obtained from the subjects interviewed by the researchers where when interviewed they mentioned that some parents never told them to go to court, as for the reason they worshipped not because of parents' encouragement but they felt very happy to attend worship because it was very pleasant. This is very consistent with the conclusions obtained from the analysis of data from questionnaires filled out by parents. To build the students' character, the role of parents needs to be improved and also the cooperation between parents, campus spiritual institutions, and also lecturers need to be held and improved to build the character of the students [36, 37, 38]. Thus, the purpose of this research has been achieved. The purpose of this study is how the active role of the family in building the character of student, and this is seen in the analysis of the data that has been done above, where after all the data is found that the role of parents in building the students' character at Universitas Kristen Indonesia is not very influential and as for the character-building is more influenced by other factors.

\section{Conclusion and Suggestion}

Based on the results of this study it can be concluded that: a) Parents do not play an active role in building the character and growth of students' faith at Universitas Kristen Indonesia, because only some parents play an active role in building the character of their children; and b) Those who play an active role in building the character and growth of students' faith at Universitas Kristen Indonesia are lecturers, churches, and campus spiritual service who make various efforts that are very directly related or carry out activities that have a large contribution in building character and growth student faith. Thus, it is recommended that: a) the family as a place where students live, and as a starting place to receive education should be more active in building the character and growth of faith in students. The role should not only be done by other parties such as pastors, student lecturers or others in building the character of students, and b) in building the character of students, the parents and the church and religious teachers must cooperate, so that the characterbuilding Universitas Kristen Indonesia went in harmony and produced good fruit. It is expected that all parents everywhere, both churches everywhere, carry out various activities which are very direct in building the character at Universitas Kristen Indonesia. 


\section{References}

[1] Richard R Clayton. 2003. The Family, Mariage and Social Change.

[2] Jhonson, C.L. 1988. Ex Familia. New Brunswick: Rutger University Press.

[3] Baron, R. A dan Donn Byrne. 2003. Psikologi Sosial. Jakarta: Erlangga

[4] Briton Bill. 2009. 10 Karakter Kristus yang Harus Kita Contoh. Diakses: 11 Appril 2011.

[5] Denny Teguh Sutandio, 2009. Christian faith and maturity, Diakses Selasa, 20 April 2011.

[6] Ndaomanu Charles. Kwalifikasi Perubahan Iman Kristen. Diakses: 11 Appril 2011.

[7] Santoso. P. Magdalena. 1989. Hakekat Sekolah Minggu. Jurnal Pelita Zaman Vol. 4 No. 1 Tahun 1989.

[8] Joseph Murphy D.R.S., 2002. Rahasia Kekuatan Pikiran Bawah Sadar. Jakarta, SPEKTRUM.

[9] Megawangi, Ratna, 2003. Pendidikan Karakter untuk Membangun Masyarakat Madani. IPPK Indonesia Heritage Foundation.

[10] Kamus Besar Bahasa Indonesia, (Jakarta: Balai Pustaka, 1999), Cet. Ke- 10, h. 787

[11] Alkitab dengan kidung jemaat (Jakarta: Lembaga Alkitab Indonesia, 2005)

[12] Pdt. Dr. Vivian Andriani Soesilo. Penegertian keluarga. Diaksese Senin, 23 April 2011

[13] Latifah Melly. Peranan Keluarga dalam Pendidikan Karakter Anak. (2008). Diakses: 11 Appril 2011.

[14] N. K. Singh dan Mr. A.R. Agwan, Encyclopaedia of Religion, (New Delhi: balaji Offset, 2000) Edisi I h. 175

[15] Rhonda Byrne, The Secret, (Jakarta: PT Gramedia, 2007), h.17

[16] Joseph Murphy D. R. S., Rahasia Kekuatan Pikiran Bawah Sadar, (Jakarta, Spektrum, 2002), h. 6.

[17] Adi W. Gunawan, Hypnosis - The Art of Subconscious Communication, (Jakarta: PT Gramedia Pustaka Utama, 2005) h. 27-30

[18] Adi W. Gunawan dan Ariesandi Setyono, Manage Your Mind for Success, (Jakarta: PT. Gramedia Pustaka Utama, 2006) h. 38

[19] Ariesandi, S. (2006). Hypnoparenting: Menjadi Orangtua Efektif dengan Hipnosis, (Jakarta: PT. Gramedia Pustaka Utama, 2006), h. 50

[20] Melly, L. Peranan Keluarga dalam Pendidikan Karakter Anak. (2008). Diakses: 11 Appril 2011

[21] Dougherty, T. \& Kurosaka, L. 2002. USCB Study of Children from Fatherless Homes. http://www.fathermag.com/news/2776-USCB.shtml.(12/14/02)

[22] Evans, G.D., The Common Roles of Fathers: The Five Ps. http://edis.ifas.ufl.edu/Body_HE140. $(12 / 18 / 02.1999$.

[23] Paul Anderson. Building Christian Character. Bethany House Publishers, Minnesota - USA. 1980.

[24] Brown, T. 2000. What Special About Father's Involvement? http://www.balconesbank.community.com/voices/father.asp. (12/16/02).

[25] Byrum, S. 1996, New Roles for Dads: Father as Role Models and Mentors. http://www.negs.org/. (12/16/02)

[26] Barbara A. Lewis. Character Building untuk Anak-anak. (Kharisma: Batam. 2004)

[27] ESRC. 2001. Father Involvement and Outcomes in Adolescence and Adulthood. http://www.Literacutrust.org.UK/Research/fatherinvolve.tm/. (12/16/02).

[28] Naibaho, L. (2019). Teachers' Roles on English Language Teaching: A Students Centered Learning Approach. International Journal of Research-Granthaalayah, 7(4), 206-212.

[29] Tyas, E. H., \& Naibaho, L. (2019, November). The urgency of entrepreneurship learning in the industrial age of 4.0. In Journal of Physics: Conference Series (Vol. 1387, No. 1, p. 012032). IOP Publishing.

[30] Arikunto, Suharsimi. 2002. Prosedur Penelitian Suatu Pendekatan Praktek, Jakarta: Rineka Cipta.

[31] Nadeak, B., \& Naibaho, L. (2018). The Description of medical students' interest and achievement on anatomy at faculty of medicine Universitas Kristen Indonesia. International Journal of Sciences: Basic and Applied Research (IJSBAR), 39 (1), 121-133. 
DOI: 10.5281/zenodo.3631873

[32] Nadeak, B., \& Naibaho, L. (2019, November). Investigating the effect of learning multimedia and thinking style preference on learning achievement on anatomy at Universitas Kristen Indonesia. In Journal of Physics: Conference Series (Vol. 1387, No. 1, p. 012116). IOP Publishing.

[33] Haryono, Amirul Hadi. 1988. Metodologi Penelitian Pendidikan, Bandung: Pustaka Setia.

[34] Tyas, E. H., Sunarto, S., \& Naibaho, L. (2018). Evaluasi Implementasi Pembelajaran Students Centered Learning oleh Mahasiswa PPL FKIP-UKI Di Sekolah Mitra-PSKD. Jurnal Selaras: Kajian Bimbingan dan Konseling serta Psikologi Pendidikan, 1 (1), 69-80.

[35] Semiawan, C.R. 1999/2000, Perkembangan dan Belajar Peserta Didik. Jakarta: Depdikbud Dirjen PT. Suhartono, I. 1999, Metode Penelitian Sosial. Bandung: PT Remaja Rosdakarya.

[36] Naibaho, L. (2014). Peran Pendidikan dan Kebudayaan dalam Pembangunan Karakter dan Peradaban Bangsa Indonesia yang Majemuk. Jurnal the Ary Suta Center Series on Strategic Management, 27 (0), 69.

[37] Tyas, E. H., \& Naibaho, L. (2018). Kepemimpinan: Gaya Dan Peranannya Dalam Melaksanakan Revolusi Mental. National Proceeding. UPH Press.

[38] Nadeak, B., Deliviana, E., Sormin, E., Naibaho, L., \& Juwita, C. P. (2019). Pembinaan Ketahanan Pernikahan dan Keharmonisan Keluarga Dengan Tema "The Family Relationship and Intimacy. Jurnal ComunitÃ Servizio: Jurnal Terkait Kegiatan Pengabdian kepada Masyarakat, terkhusus bidang Teknologi, Kewirausahaan dan Sosial Kemasyarakatan, 1(2), 179-185.

*Corresponding author.

E-mail address: tyasyes@ gmail.com/lamhot.naibaho@uki.ac.id 